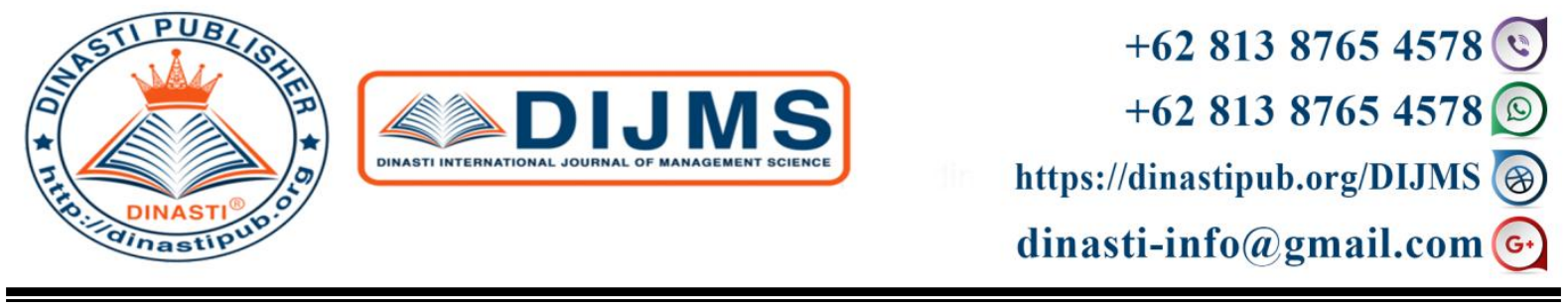

\title{
THE ROLE OF MOTIVATION ON ORGANIZATIONAL COMMITMENT OF MANAGEMENT PROGRAM S1 LECTURERS AT PRIVATE UNIVERSITIES IN THE CITY OF BANDUNG
}

\section{Muji Rahayu}

STIE STAN IM, Bandung, Indonesia

\begin{tabular}{|l|l|}
\hline ARTICLE INFORMATION & $\begin{array}{l}\text { Abstract: This study wants to examine whether } \\
\text { Received: } 19^{\text {th }} \text { April } 2020 \\
\text { metivation affects the organizational commitment of } \\
\text { lssued: } 08^{\text {th }} \text { May } 2020\end{array}$ \\
$\begin{array}{l}\text { lecturers. The population is a Lecturer in Management } \\
\text { Study Program of a private university in the city of } \\
\text { Bandung. The total sample of 50 Management Study } \\
\text { Program Lecturers is taken randomly. Data was } \\
\text { collected by means of a survey using a questionnaire. } \\
\text { Furthermore, the data is processed using a simple } \\
\text { E-mail: }\end{array}$ & $\begin{array}{l}\text { linear regression method to find out and analyze the } \\
\text { effect of motivation on the organizational commitment } \\
\text { of lecturers. It is hoped that the results of this research } \\
\text { can increase the motivation of lecturers, which in turn } \\
\text { can increase the organizational commitment of } \\
\text { lecturers. The results showed that motivation has a } \\
\text { positive and significant influence on organizational } \\
\text { commitment of Management Study Program lecturers } \\
\text { in Bandung. }\end{array}$ \\
Keywords: Motivation, Organizational Commitment.
\end{tabular}

\section{INTRODUCTION}

There has been a significant increase in unemployment in the last five years. Based on BPS data for 2018. In Bandung the highest number of unemployed comes from university graduates, amounting to 27,500 people. This shows that the quality of university graduates is not in accordance with the demands of employment or employment industries. The quality of graduates who are not in accordance with the expectations of employers is a sign that the performance of higher education has not yet reached the target set. Factors that are seen to affect performance include organizational motivation and commitment. (Wirawan,2012).

There are several results of research on organizational motivation and commitment. Motivation is predicted as a factor that can influence organizational commitment (Choong, 2011). Some others show that organizational motivation and commitment are predicted as 
factors that can improve performance. (Hairuddin et al., 2017); Rahardja et al., 2017); Suryaman, 2018).

Motivation as a force that drives a person to behave in a certain effort to achieve goals. Strong motivation is very necessary and important in improving performance. Some experts claim that motivation is something that raises enthusiasm or drive work to carry out work in accordance with the target. (Robbins, 2015; Gibson, 2016; Sutrisno, 2013). Motivation can be used as a strategy to improve employee performance. Because employee performance is not in accordance with performance targets, one of which is caused by low employee motivation. (Silalahi, 2015). Only $60 \%$ of the lecturers who hold the certification of lecturers conduct research (LLDIKTI IV, 2019). This data shows that certified lecturers do not have commitment. This causes organizational goals can not be achieved according to the expected target.

Based on the description above and the results of previous studies, the hypotheses in this study are:

H1: There is a motivational effect on organizational commitment.

\section{LITERATURE REVIEW \\ Motivation}

Motivation is the power that drives a person to behave in a certain effort to achieve goals. Therefore motivation is very necessary and important in improving performance. Motivation is something that gives rise to enthusiasm or work motivation to carry out work in accordance with the target. (Robbins, 2015; Gibson, 2016; Sutrisno, 2013). Employee performance that is not in accordance with performance targets, one of which is caused by employee motivation. (Silalahi, 2015). There are 3 (three) dimensions of motivation, including (1) achievement motivation (need of achievement), (2) friendly motivation (need of affiliation), and (3) motivation of power (need of power). (Mc. Clelland ,1961). In achievement motivation, indicators can be seen in individual attitudes between: like achieving individual performance, accepting moderate challenges (according to ability), happy to receive feedback on performance, often doing work in new ways. Motivation can be used as a strategy to improve employee performance

\section{Organizational commitment}

Organizational commitment is interpreted as a strong desire to remain a member of an organization, willingness to work hard on behalf of the organization and trust and individual acceptance of the values and goals of the organization. Commitment is determined by personal variables and organizational variables. Personal variables include age, tenure in the organization, individual dispositions such as positive or negative affective and control of attribution both internal and external. Whereas organizational variables include job task design and leadership style (Luthans, 2006). However, organizational commitment has a broader meaning beyond mere passive loyalty. Organizational commitment is a level of employee loyalty to the organization which is characterized by its desire to remain part of the organization, maintain the good name of the organization and do its best to make a 
meaningful contribution to the organization. (Mowday et.al, 1982 ; Steer, 1985; Triatna,2015).

\section{RESEARCH METHODS \\ Research Type}

This research uses quantitative, descriptive and verification methods. The results of the study are presented in the form of quantitative data (numbers), then interpret the meaning and describe the independent variable data without being linked with other variables. (Siregar, 2013)

\section{Population and Sample}

The population is a Lecturer in Management Study Program of a private university in the city of Bandung. The technique of determining the sample using random sampling. The total sample of 50 respondents, came from 13 private universities in the city of Bandung.

\section{Data Collection and Processing}

The technique of collecting data is by distributing questionnaires conducted from November 10, 2019 to January 25, 2020. The motivation questionnaire consisted of 10 statements and the organizational commitment questionnaire consisted of 10 statements. Furthermore, the data obtained were processed using the excell application program, SPSS version 23. In this verification study, it is intended to prove the hypothesis that there is an influence of motivation on organizational commitment Lecturer of Management Study Program in Bandung.

\section{FINDINGS AND DISCUSSION}

\section{Respondent Data}

Table 1. Gender

\begin{tabular}{ccc}
\hline Gender & Frekuensi & $\%$ \\
\hline Male & 33 & 66 \\
\hline Female & 17 & 34 \\
\hline Amount & 50 & 100 \\
\hline
\end{tabular}

\section{Source: Data Processing 2020}

Based on the data above, there are more male respondents than women. This is because men are responsible for meeting the needs of their family life.

Age

Table 2. Age

\begin{tabular}{ccc}
\hline Age & Frekuensi & $\%$ \\
\hline$<30$ & 6 & 12 \\
\hline $31-35$ & 5 & 10 \\
\hline $36-40$ & 11 & 22 \\
\hline $41-45$ & 9 & 18 \\
\hline $46-50$ & 7 & 14 \\
\hline $51-55$ & 7 & 14 \\
\hline
\end{tabular}




\begin{tabular}{rcc}
\hline $56-60$ & 5 & 10 \\
\hline Amount & 50 & 100 \\
\hline
\end{tabular}

Source: Data Processing 2020

Based on age, the highest number of respondent ages is 36 - 40. At that age lecturers usually have the academic rank of Expert Assistant and already have lecturer certification. this causes lecturers to tend to easily help other lecturers who conduct research because they already feel how difficult it is to conduct research.

Table 3. Position

\begin{tabular}{ccc}
\hline Position & frekuensi & $\%$ \\
\hline $\begin{array}{c}\text { Not Yet An Expert } \\
\text { Assistant }\end{array}$ & 4 & 8 \\
\hline Expert & 24 & 48 \\
\hline Lecturer & 17 & 34 \\
\hline Head Lecturer & 5 & 10 \\
\hline Amount & 50 & 100 \\
\hline
\end{tabular}

Source: Data Processing 2020

The most functional positions are Expert Assistants. This is because the respondents chosen are those who already have lecturer certifications which usually have at least a functional Assistant Expert position.

\section{Education}

Table 4. Education

\begin{tabular}{ccc}
\hline Education & Frekuensi & $\%$ \\
\hline Strata 2 & 35 & 70 \\
\hline Strata 3 & 15 & 30 \\
\hline Amount & 50 & 100 \\
\hline
\end{tabular}

Source: Data Processing 2020

Based on table 4. Explained that the highest level of final education is Strata 2. This is because as a requirement to become a lecturer is Strata 2 .

\section{Data Processing Results}

The following is the instrument test results presented in this study which include the validity and reliability tests as shown in the table.

Table 5. Validity Test

\begin{tabular}{lll}
\hline Variable & Score & Decision \\
\hline Motivation & $0,559-0,835$ & Valid \\
\hline Organizational Commitment & $0,381-0,888$ & Valid \\
\hline Source: Data Processing 2020 & &
\end{tabular}

Table 5. Explains that the validity score of organizational motivation and commitment is more than 0.3. This means that all data used is valid.

\section{Reliability Test}

Table 6. Reliability Test

\begin{tabular}{lll}
\hline Variable & Score Cronbach Alpha & Decision \\
\hline Motivation & 0,919 & Reliable \\
\hline
\end{tabular}




Organizational Commitment $\quad 0,890 \quad$ Reliable

\section{Source: Data Processing 2020}

Table 6. Explains that the reability score of organizational motivation and commitment is more than 0.6. This means that all data used is reliable.

\section{Normality Test}

Table 7. Normality Test

\begin{tabular}{llrr}
\hline & & \multicolumn{2}{c}{ Organizational } \\
\hline $\mathrm{N}$ & & Motivation & Commitment \\
\hline Normal Parameters & & 50 & 50 \\
& Mean & 38.4000 & 40.6400 \\
\cline { 2 - 4 } & Std. Deviation & 5.26831 & 5.39751 \\
\hline Most Extreme & Absolute & .181 & .187 \\
\cline { 2 - 4 } & Positferences & .181 & .187 \\
\cline { 2 - 4 } & Negative &. .175 & -.112 \\
\hline Test Statistic & & .181 & .187 \\
\hline Asymp. Sig. (2-tailed) & & $.120^{\mathrm{c}}$ & $.117^{\mathrm{c}}$ \\
\hline Source: Data Processing 2020 & &
\end{tabular}

In table 7 . It can be seen that the significance asymp value $>0.05$. this shows that all data are normally distributed.

\section{Descriptive test}

Table 8. Descriptive test

\begin{tabular}{lrrrrr}
\hline & $\mathrm{N}$ & Minimum & Maximum & Mean & Std. Deviation \\
\hline Motivation & 50 & 2.50 & 4.90 & 3.45 & 0.5268 \\
\hline $\begin{array}{l}\text { Organizational } \\
\text { Commitment }\end{array}$ & 50 & 3.00 & 5.00 & 4.06 & 0.5397 \\
\hline Valid N (listwise) & 50 & & & & \\
\hline
\end{tabular}

Source: Data Processing 2020

Based on the descriptive test results, it is known that the average score of motivation is 3.45 (good enough). Because high motivation will increase organizational commitment of lecturers. While the average score of organizational commitment is 4.06, included in the good category. The organizational commitment of lecturers can increase to very good if the motivation of lecturers also increases. Therefore the thing that needs to be done is how to increase the motivation of lecturers.

On the motivational variable, the respondent's answer shows that the lowest score is in the Lecturer statement repairing a disturbed relationship (need of affiliation). The highest score is that the lecturer likes a job with a moderate level of difficulty. (Need of Achievement)

Therefore, in order to increase motivation, motives for affiliation and achievement need to be improved. Factors that increase motivation can come from internal and external individuals. For example, expectations, job satisfaction, work environment, employee benefits system. 


\section{Corellation Test}

The following is a table about the correlation between motivation and organizational commitment.

Table 9. Correlation Test

\begin{tabular}{llrr}
\hline & & & \multicolumn{2}{c}{ Organizational } \\
Motivation & Motivation & Commitment \\
\cline { 2 - 4 } & Pearson Correlation & 1 & $.869^{* *}$ \\
\cline { 2 - 4 } & Sig. (2-tailed) & & .000 \\
\cline { 2 - 4 } $\begin{array}{l}\text { Organizational } \\
\text { Commitment }\end{array}$ & Pearson Correlation & $.869^{* *}$ & 50 \\
\cline { 2 - 4 } & Sig. (2-tailed) & .000 & 1 \\
\cline { 2 - 4 } & $\mathrm{N}$ & 50 & 50 \\
\hline
\end{tabular}

Source: Data Processing 2020

The correlation value between motivation and organizational commitment is 0.869 . This means it has a very strong correlation

\section{t test and Simple Linear Regression Equation and Test of Significance}

\section{Table 10. Coefficient}

\begin{tabular}{|c|c|c|c|c|c|c|}
\hline \multirow[b]{2}{*}{ Model } & & \multicolumn{2}{|c|}{ Unstandardized Coefficients } & $\begin{array}{l}\text { Standardized } \\
\text { Coefficients }\end{array}$ & \multirow[b]{2}{*}{$\mathrm{T}$} & \multirow[b]{2}{*}{ Sig. } \\
\hline & & $\mathrm{B}$ & Std. Error & Beta & & \\
\hline \multirow[t]{2}{*}{1} & (Constant) & 6.470 & 2.840 & & 2.278 & .027 \\
\hline & Motivation & .890 & .073 & .869 & 12.142 & .000 \\
\hline
\end{tabular}

a. Dependent Variable: Organizational Commitment

Source: Data Processing 2020

Based on table 10 can be obtained linear regression equation as below:

Regression Equation

$$
\begin{aligned}
& \mathrm{Y}=\mathrm{a}+\mathrm{b} \mathrm{X}^{(1)} \\
& \text { Information: } \\
& \mathrm{Y}=\text { Organizational Commitment } \\
& \mathrm{a}=\text { constant } \\
& \mathrm{b}=\text { Regression coefficient } \\
& \mathrm{X}=\text { Motivation } \\
& \mathrm{Y}=6.470+0.890 \mathrm{X}
\end{aligned}
$$

That means:

If without motivation, the value of lecturer organizational commitment is only 6.470. With motivation, the commitment value of the lecturers' organization has changed to increase from 6.470 to 6.470 plus 0.890 at 7.360

$\mathrm{t}$ count value of 12.142 is greater than $t$ table. This means that there is a positive influence of motivation on organizational commitment.

Test of Significance

The significance value of 0,000 is smaller than 0.05 . This means that there is a significant influence of motivation on organizational commitment.

Based on the results of data processing, it can be concluded that there is a positive and significant influence of motivation on organizational commitment. 


\section{Coefficient of Determination}

Table 11. Coefficient of Determination

\begin{tabular}{cc}
\hline $\mathrm{R}$ & $R$ Square \\
\hline .869 & .754 \\
\hline
\end{tabular}

Source: Data Processing 2020

The coefficient of determination is:

$\mathrm{R}^{2} \mathrm{X} 100 \%$

$0.754 \times 100 \%=75.4 \%$

This means that motivation contributes to organizational commitment by $75.4 \%$ while the remaining $24.6 \%$ is influenced by other variables not examined in this study. Examples of competency, job satisfaction and others.

\section{CONCLUSION AND SUGESTION}

Based on the results of data processing, the correlation coefficient between motivation and organizational commitment is 0.869. Based on the guidelines on interpretation of relationship correlations, the score is included in the very strong category. This shows that organizational commitment with motivation has a very strong relationship. Therefore to increase organizational commitment, motivation must first be increased.

$\mathrm{T}$ count value of 12.142 is greater than $\mathrm{t}$ table. This means that there is a positive influence of motivation on organizational commitment. The significance value of 0,000 is smaller than 0.05. This means that there is a significant influence of motivation on organizational commitment.

Based on these findings it can be concluded that motivation has a positive and significant influence on organizational commitment. This is in line with the results of research conducted by Choong, (2011), Hairudin (2017), Rahardja (2017) and Suryaman (2018)

\section{REFERENCE}

Choong. (2011). Intrinsic Motivation and Organizational Commitment in The Malaysian Private Higher Education Institutions. . International Refereed research Jounal. Vol.II, Issue-4, , 91.

Gibson. (2016). Organization, Behavior, Structure, Processes. New York: Mc Graw Hill Education.

Hairudin. (2017). Motivation, Competence, and Organizational Commitment's Effects On Lecturers' Job Satisfaction and Lecturers Performance. International Journal of Management \& Social Sciences (ISSN 2445 -2267) 6 (3) , 419-428.

IV, L. (2019). Beban Kerja Dosen Program S1 Manajemen Universitas Swasta Se-Bandung. Bandung: LLDIKTI IV.

Luthans. (2006). Perilaku Organisasi. Yogyakarta: Andi.

Rahardja et al. (2017). Leadership Competency, Working Motivation and Performance Of Higher Private Education Lecturers with Institution Accreditation B Area Kopertis IV Banten Province. Man In India, 179-182.

Silalahi. (2017). Asas - Asas Manajemen. Bandung: Refika Aditama. Siregar. (2013). Metode Penelitian Kuantitatif. Jakarta: Kencana Prenada Media Group. 
Suryaman. (2018). Indonesia Private University Lecturer Performance Improvement. Model To Improve a Sustainable Organization Performance. International Journal of Higher Education, 59-68.

Sutrisno. (2013). Manajemen Sumber Daya Manusia. Jakarta: Kencana Prenada Media Group.

Triatna. (2015). Perilaku Organisasi Dalam Pendidikan. Bandung: Remaja Rosdakarya. Wirawan. (2012). Evaluasi Kinerja Sumber Daya Manusia. Jakarta: Salemba Empat. 